\title{
Some ECONomic Characteristics of InTERnet Platforms
}

\author{
Peter Plavčan $^{1}$, Rastislav Funta ${ }^{2}$
}

\begin{abstract}
Various internet platforms have rapidly developed into central points of everyday life, for private individuals as well as for companies (often dominated by a single or a few companies). At the same time these internet platforms are advancing into more and more areas of business. This creates the risk of dependency, abuse of power, manipulation, concentration of power, centralization of data and information with corresponding effects on technological development, innovation, economy, society and politics. From an economic point of view, this article examines how the strong market positions of internet platforms arise and can be maintained. The dynamics of these technology and innovationdriven markets and the differences from conventional markets are also discussed. These internet markets have emerged from a series of innovations and are characterized by rapid technological development. Taking into account the economic peculiarities as well as knowledge from innovation and governance research, recommendations are drawn up on how these problems can be dealt with.
\end{abstract}

\section{Keywords}

Internet Platforms, Innovations, Lock-in Effect, Technological Development

\section{Introduction}

From an economic point of view, there is room for beneficial investment by the state if competition in a certain market cannot play properly. The functioning of imperfect markets serves as the basis for economic regulatory recommendations. Conventional regulatory recommendations are based on traditional economic models, which are not tailored to a highly technological environment characterized by network effects. Regulation of these innovation-based markets should therefore take their special characteristics into account. Before the particular economic properties of internet platforms can be explained, basic economic assumptions have to be discussed (Funta, 2020). First of all, reference is made

\footnotetext{
${ }^{1}$ Danubius University, Richterova č. 1171, 92521 Sládkovičovo, Slovak republic. E-mail: peter.plavcan@vsdanubius.sk.

${ }^{2}$ Danubius University, Richterova č. 1171, 92521 Sládkovičovo, Slovak republic.

E-mail: rastislav.funta@ vsdanubius.sk.
} 
to the two main assumptions of welfare economics. On the one hand, a general equilibrium with perfect competition is considered pareto-optimal, i.e. allocation through the market brings all consumers an optimal level of benefit (Šmejkal, 2012). The second assumption is that any pareto-optimal allocation can be brought by the market by setting the price at the level of the marginal cost of a product (goods), and thus real income allocation between consumers. The third assumption is sufficient size of market. This paradigm presupposes the absence of externalities and the complete information of the consumers, moreover it must be private goods. All of these three prerequisites are only partially or not at all met by markets with internet platforms, which is why appropriate adjustments to the models are necessary. In the following, the essential economic peculiarities of internet business models should therefore be discussed in detail, which can sometimes lead to competition in these markets often not being able to play effectively. Some economic peculiarities of internet business models often lead to an oligopolistic competitive structure, which can have a negative impact on the functioning of competition (Svoboda, Munková, Kindl, 2012). While the sphere of influence of the dominant internet platforms encompasses more and more areas of life, their enormous importance is only slowly gaining in the awareness of other circles of society, economy and science. The largely invisible big data machinery is moving largely under the radar of state regulators. Reports on influencing opinions, but also the manipulation of markets show the enormous (abuse) potential (Klimek, 2019) of gigantic amounts of data in the hands of a few Internet companies. The variety of existing debates and conflicts surrounding Internet platforms is also a reflection of the enormous importance of these platforms. These controversies also show weaknesses and limitations of traditional economic and legal concepts and create questions about the existing regulatory framework. Thus, with regard to internet platforms, there is clearly a need for research at the interface of innovation research, business strategy, market regulation, information economy and law.

\section{The term "internet platform"}

In the context of this article, various internet services are summarized under the term "internet platform" with sometimes completely different business models. It is common to the operators of these internet platforms that a central part of their business activities takes place on or via the internet (online). Internet platforms serve at least two market sides, on the one hand by offering the "manufacturers" products (goods or services) a platform, on the other hand to get in touch with their "consumers", whereby the boundaries between "manufacturers" and "consumers" are sometimes blurred. The internet platforms therefore primarily act as intermediaries, but are also offering their own products, services and content (e.g. Amazon Kindle E-Reader or Amazon Web Services).

In order to take into account, the importance of such platform-specific services and goods, the term internet platforms is used in this article (and not the term internet intermediaries). In this sense, "internet platform" includes following business models:

* E-commerce companies (sale of own or third-party products via the internet).

* Content platforms (collecting or generating content and providing a platform for it).

* Online service providers (offering and performing services over the internet). 
* Social networks.

* Market Makers (intermediaries).

Internet platforms such as Amazon, Google, Facebook or eBay, unlike many others, have been able to grow successfully over the years (Funta, 2018). The term internet platform should therefore be understood as comprehensively as possible in order to distinguish it from the existence of certain internet models and also to capture future developments in this rapidly changing environment.

\section{Economic characteristics of internet platforms}

Network markets, which often appear in the areas of transport, communication and information, are an integral part of modern economic and social life. Internet platforms are typical examples of such services and have their particular economic characteristics. A thorough knowledge of these economic peculiarities is therefore necessary for an understanding of the functioning of internet markets and their differentiation from conventional markets. Therefore, the features of information goods and two-sided markets, network effects and lock-in effects and finally the effects of these features on the emergence and stability of monopolies in the area of internet platforms are discussed below.

\section{Information assets (goods)}

When using a website or digital data, there is no rivalry between different users, since the consumption of one user does not fundamentally affect other users (Mesarčík, 2018). The supplier also hardly incurs any additional costs for each additional user, since the variable costs are negligibly small compared to the fixed costs and the suppliers can thus benefit from economies of scale. Another decisive factor in the emergence of oligopoly or monopoly situations is the fact that there are hardly any capacity restrictions, which means that a single provider can potentially cover all of the demand on its own and thus also achieve the lowest costs per user. As a result, because the largest company benefits from the greatest cost advantages, being the largest company in a particular market can lead to intense competition between companies. This in turn can result in cost advantages for consumers (Amazon's growth strategy based on economies of scales). Since information goods can be replicated extremely easily and with little effort, the exclusion of third parties is often only possible through intellectual property rights such as copyright, patent law and the protection of business secrets (Daňko, Žárská, 2019). The non-rivalry and the difficulty of excluding someone from the use bring the information goods from an economic point of view close to public goods (Beňová, Cibáková, Plavčan, 2005). However, they differ from public goods, particularly in the form of physical infrastructure, in most cases by significantly lower production costs.

\section{Multi-sided markets}

Internet platforms typically operate in two-sided or multi-sided markets (Šmejkal, 2016). For example, the Google search engine as an advertising platform for various companies and private individuals, while the search engine users and potential customers of these 
companies are on the other side of the market (Funta, 2016). Amazon is also a sales platform for companies such as publishers and is also an online purchase platform for individual customers. The versatility of these markets enables the internet platforms to provide part of their services on one of the sub-markets free of charge and thereby achieve high user numbers. With the resulting increased user base, the willingness to pay by the other user group, for example for advertising services, can in turn be increased. However, free of charge does not mean without consideration, because internet users pay for the relevant services of the internet platforms with their data and their attention and thereby enable other forms of financing, for example through (personalized) advertising. The size of internet platforms such as Amazon and Google are particularly attractive because it provides a comprehensive offer for users. As two-sided platforms, Google and Amazon become more attractive for each market side (advertising companies or publishers) with the increasing number of participants on the other market side (potential customers and user data). There are therefore positive externalities caused by the interaction of both market sides, which are also referred to as indirect network effects. The versatility of these markets is reflected in the financing structure of the internet platforms, which is based on a "third-party payer" model: The internet platform operator (1st party) offers its users (2nd party) its services or goods free of charge, while a third group (3rd party) must pay for participation.

\section{Network effects}

The theoretical foundations for economic theories about network effects were laid down at the end of the 19th century. The benefit of a certain good for the consumer often depends on the number of other consumers who use the same good, and it increases disproportionately with each additional consumer due to increasing economies of scale. For each individual user, the value of a network generally increases proportionally with the number of users, whereas from the point of view of social welfare, the overall benefit of a network increases disproportionately to the number of users. This discrepancy of network externalities between the benefit for the individual and the overall benefit for the community leads to market results that may not correspond to the pareto balance (Králiková, 2016). Due to the network effects, each additional user creates added value for the community of all participants. The value of a network good does not only increase with the number of users, but rather with the number of expected users. If a user has the choice between different internet platforms, he takes his decision primarily on the use of the associated network and on the independent use of this platform. The benefits of network effects depend heavily on the positive network externalities by enlarging the network which copies asks of customers. System goods (examples of such system goods are telecommunications services or trading services in the context of electronic business-to-business marketplaces or electronic auctions, Daňko, 2019) have only a derived, network-dependent benefit, since they do not provide any benefit in themselves and are therefore useless if they are not used by other users. Most internet platforms fall into this category, since they would bring little or no benefit to a single user. 
We can distinguish three different reasons for positive consumer externalities:

* First, direct consumer externalities can result from an immediate effect of the number of users on the quality of the product (e.g. telephone and other means of communication);

* Second, indirect consumer externalities can arise from the number of users if the users of a larger network have more compatible complementary products at their disposal (e.g. game consoles and video games);

* Third, positive consumer externalities can arise in the case of durable products if the quality of the additional service and support services increases with the size of the network.

Such network effects already appeared before the spread of the internet. Using the example of the telephone, or the standard software from Microsoft, it can be clearly shown that technological standardization associated with the expansion of the network can also have certain positive effects from an economic perspective (Polčák, 2018). Such network effects can be observed regularly on internet platforms. In the case of an individual user, however, the use of friends and (work) colleagues can be more decisive than the mere number of users, especially for social networks. In addition, socially motivated, positive network effects can occur if, for example, users want to use a certain internet platform to signal belonging to a certain group. We can identify a market failure caused by network effects. If the network effects are pronounced, standardization or monopolization takes place without state intervention, so that only one provider remains active in the market. A company that is the first to appear in a certain market can lock it off from new companies, even if they offer superior services and products and thus act as a barrier to innovation. Such a market failure occurs particularly in duopoly situations, whereas an efficient market balance could also be achieved without government intervention if the network effects of the technologically superior company are strong enough. The widespread offering of free services through internet platforms can be seen as a competitive price strategy, because it is primarily intended to create the largest possible user network or a strong market position. Companies like Microsoft or Apple often cooperate with providers of complementary goods such as apps or other software products.

\section{Lock-in effects}

Established providers in internet markets, despite supposedly low entry barriers, cannot easily be pushed out of their position. In view of the pronounced network effects, a switch to a different (new) provider is usually only possible for users if they encounter there a sufficient number of other users, since they decisively determine the attractiveness (and the benefits) of a platform. This results in an inflexibility of the market. This lock-in effect is further enhanced when users adapt to a specific platform. The lock-in effect can be further intensified if software is used for the use of certain services on an internet platform that is incompatible with that of competitors or a transfer of previous data is prevented. A lack of interoperability and compatibility can therefore further intensify a high market 
concentration by increasing the lock-in effect. The transition from a previously used internet platform to a new one is therefore associated with certain switching costs for the user. These switching costs weaken the competition between existing companies in a market (Whish, Bailey, 2018). Nevertheless, switching costs attract new companies that want to serve the potential users in a market. However, entering an existing network market is difficult for various reasons: For first time users there is a risk that the new platform has too little network potential or that they choose the "wrong" platform, which increases the switching costs. An early switch to the "right" platform, on the other hand, can enable users to benefit from the advantages of this superior platform earlier and for longer period. The timing of the change therefore also plays a role for the user. When deciding on a specific platform, users must therefore make assumptions about the future (size) development of this platform and its competitors. In order to be successful, a new internet platform must succeed in convincing the first-time users of their great development potential. This is accompanied by assumptions about the decision-making behaviour of future users, which in turn are influenced by the decisions of today's users. The lock-in effect can be very profitable for an internet platform, since the respective company can set monopoly prices with a strong lock-in effect and thus skim the entire monopoly profit. Many users are e.g. familiar with the functionality of the Google search engine (Funta, 2014) or the Amazon website and also have their own user accounts. These also make handling easier for them, e.g. by simplify and speed up the Amazon buying process (LaVecchia, Mitchell, 2016). If they switch to a different platform, this knowledge is not immediately applicable, and the benefits have been lost accordingly. Most users therefore use the same search engine as standard and do not switch between different search engines. We meet also with the socalled education of the future consumers, when individual providers of different platforms these offer free of charge to secondary schools and higher education institutions for school training. Graduates of these institutions after taking practice mostly prefer this platform, if the employer will allow the selection.

\section{Historical coincidences}

The market conditions in network markets are often determined by historical events and coincidences. While the market balances in other markets can usually be determined on the basis of consumer preferences and quality standards, the market result in network markets often appears random and can only be understood based on historical development. If on a certain internet market, e.g. due to network effects, only a dominant internet platform exists and the lock-in effect creates difficulties for new companies wishing to enter the market, the dominant company is often determined by historical events and not by different strategies of companies (Funta, 2010). Due to the network effects, an early lead in network size can be sufficient to quickly dominate a market and successfully exclude other providers. A great impact on the decision making of the consumer while deciding on a new internet service has also the brand and the long-term status (market position) of providers on the internet market. 


\section{Temporary monopolies}

The combination of economies of scale and network effects leads to a self-reinforcing growth cycle, which appears by a certain critical mass of users. If this critical mass cannot be achieved, a platform is doomed to fail. This risk represents a barrier to entry. A company receives more attention, if the user base is larger and can also benefit from referrals. These self-reinforcing growth spirals lead to strong market players becoming stronger and weaker ones weaker. This in turn results in a concentration towards a "winner takes it all" or "loser gets nothing". In practice, this concentration can be determined, for example, for the market for search engines (Google) and in the area of sales portals (Amazon). The success of a platform depends crucially on its ability to cross the critical mass threshold (Daňko, Mesarčík, 2015). A new internet platform can only reach the critical mass of users if it either already has the necessary number of users through another platform or the user data is publicly accessible. The stabilization and expansion of the market power of already established internet companies will also be facilitated by the economic resources. The superior financial strength of large internet companies allows them to invest massively in their own technical and logistical infrastructures, but also in general in research and development (Machová, Kotlán, 2014). The economic peculiarities of internet platforms described favour on the one hand the emergence and partly also the continued existence of oligopolies or monopolies, but on the other hand also enable (at least theoretically) a growth of new platforms. Even an internet platform with a dominant, stable market position can be displaced if its users almost completely switch to a new, more innovative platform (Funta, 2017). The behaviour of users is often volatile and unpredictable. The difficulty here is to determine to what extent a dominant company is kept in check by the possibility of a new entry, meaning to what extent there are market barriers (Karas, Králik, 2012). Long-term market power has so far been prevented in many areas by at least in the medium term through innovations. A company entering the market also has economies of scale and, from a certain number of users, network effects, so that it can potentially grow very quickly and displace an existing company (Funta, Golovko, Juriš, 2020). At the same time, a slowdown in this dynamic can be observed in some areas. This may be due to some learning effect. Today's leading internet platforms specifically buy up potential competitors and innovative know-how in order to maintain their market position and show a high adaptability, which is crucial for this environment shaped by innovations. However, the costs of developing and maintaining certain internet platforms, especially search engines, should not be underestimated. The barriers to entry are further increased by the lock-in effect and the start-up problem, both of which are significant for online markets. A monopolist and owner of exclusive rights of an innovative technology in a network market may have an incentive to invite competitors into the market in order to increase production capacity (Procházka, Čorba, 2006). This is the case if the monopolist and owner of the rights do not have sufficient production capacities and if the entry of competing producers overlaps the additional competitive pressure (Siman, Slašlan, 2010). In the presence of pronounced positive network externalities, it could be worthwhile for a monopolist to license his technology, possibly even free of charge, to the competitors and thus positively influence the potential consumers about the possible network size and 
thus the benefits of the network. However, this is only valid in relation to physical network goods, but not in relation to internet platforms, which have high economies of scale. This is due to the fact, that it seems unrealistic that internet platforms give competitors access to their technology and consciously invite them to the market or even subsidize them.

\section{Differences to traditional markets}

The dynamics of industries subject to network externalities are different from conventional industries. However, the great discrepancy between the results of conventional economic models and those that take network effects and other economic peculiarities of internet platforms and similar markets into account was met with resistance and criticism early on by advocates of traditional economic theories. According to classic competitive models, different companies fight for customers in one market. Additional companies always improve the welfare of customers and additional customers always improve the welfare of companies. In the case of internet platforms, however, the decisions made by individual users have a significant impact on the benefits for other users due to the network externalities. When it comes to setting prices, a monopolist on a network market also differs from those on conventional markets without network effects. In a conventional market, the monopolist will restrict future production because he does not want to sell at a lower price in the future. This results in a loss of welfare. If, on the other hand, a monopolist in a network market reduces its original price, it can increase the number of its customers and also the size and value of its network, thereby justifying future price increases (Petr, Tonarová, 2010). Monopolists in network markets therefore have no incentive to artificially restrict their production. Economic models do not lead to one, but to many possible equilibrium points, whereby it is unclear which of them produces the best result. There is some ambiguity about the existence of monopolies. Typically, the market is monopolized by a single company (Elhauge, 2009). Due to the network effects, the mere size of an internet platform offers users more advantages than a similarly large company in a conventional market. However, a monopolistic provider does not necessarily provide the greatest benefit for a single user, since, although it combines the maximum number of users, there are no incentives to optimize its services and the user is therefore not necessarily provided with the best service. Excessive competition leads to fragmentation of a network. Network markets also differ from conventional markets because the protection of innovations under intellectual property law has a different effect on the market structure (Stehlík, Hamulák, Petr, 2017). In general, it can be said that intellectual property protection rewards innovative companies and promote innovation, but it can drive up prices for their products and lead to inefficient markets. Strong network effects not only make protection of intellectual property rights more expensive, they also reinforce its effective protection. This becomes clear on the basis of the first-party advantages that occur in network markets, which are made possible by the protection of intellectual property rights and which allow the company to build up a sufficiently large network and thus maintain its lead over the competition (even after the property rights have expired). If the holder of the intellectual property rights also refuses his competitors' compatibility with his product, the effect of these rights can be expanded even more. 
The protective effect of intellectual property rights in network markets also exceeds those in conventional markets. Intellectual property rights strengthen monopoly tendencies in network markets and consolidate existing monopolies (Gregušová, Peráček, 2015).

\section{Intervention needs in the event of market failure?}

As explained at the beginning, in case of internet markets we can often recognize malfunctioning due to the special economic properties of internet platforms (Funta, 2019). From an economic point of view, the existence of a market failure represents a central and necessary prerequisite for government intervention in the market (Pelikánová, 2014). However, the sole evidence of a market failure is not sufficient for a government intervention. The relevant market failure should rather be weighed up against the risk of a possible government or regulatory failure (Pelikánová, 2014). In other words, government intervention in the event of market failure can only be justified from an economic perspective if its proper design and effective implementation lead to an increase in economic efficiency. Accordingly, the task of regulation is to compensate for market failures and, if necessary, bring political objectives that are foreign to the market to bear in mind against the market logic (Klimek, 2013). Even if, from a legal point of view, a demonstrable increase in welfare is not a mandatory prerequisite for government intervention, efficiency and effectiveness have often found their way, for example as part of proportionality (Svák, 2000).

\section{Political interference in the internet market}

State intervention is a particular problem in the Internet platform market. The purpose of this state intervention is to create positive externalities of different nature for the state, but which have a negative impact on a consumer of the service. It can be an individual or a company. In case of regulating the Internet platform market, the positive externalities for the state are mainly in the field of enforcement of state monopoly (China, Russia), but also in the protection of the service itself, intellectual property, possibility to collect user's data and to process the data for different purposes. For example, the evolution of political data is characterized by the subjectivity and scope of digital news. The extent of political campaigns, their personalization and dynamics are unprecedented (Procházka, Káčer, 2013). The data of the voters can be monitored digitally, and bulk data collection can be processed in different characteristics of these individuals. Social media platforms are information and data resources of personalities. These platforms were designed to collect personal data and to store it indefinitely (Plavčan, Funta, 2019). The fact that data regulators should have a stronger position in relation to personal data was one consequence of revealing negative externalities of Internet platforms. This has led to significant GDPR initiatives. The GDPR limitations also arise directly from the complexity of this subject matter. Regulation (EU) 2016/679 of the European Parliament and of the Council of 27 April 2016 on the protection of natural persons with regard to the processing of personal data and on the free movement of such data and repealing Directive 95/46/EC (General Data Protection Regulation. Regulation (EU) 2016/679 of 
the European Parliament and of the Council also shows this is a new legislation which has not been sufficiently proven in practice yet (Stehlík, 2008). Section 9 of the preamble states: The objectives and principles of Directive 95/46/EC remain sound, but it has not prevented fragmentation in the implementation of data protection across the Union (Mazák, Jánošíková, 2009), legal uncertainty or a widespread public perception that there are significant risks to the protection of natural persons, in particular with regard to online activity (Plavčan, Funta, 2019). One example is China, where Facebook and Google are not available, as well as Instagram or Twitter. On the other hand, Microsoft and its services are available. For this reason, Chinese use their own social networks, some have millions of users. The question is to what extent these social networks are a source of reliable information and, above all, safe from the various manipulations of the people who use them. Another country is Russia, which has successfully tested the redirection of Internet traffic to local servers, which means the application of its own RuNet Internet established under the new National Digital Economy Programme. Russia is preparing to ensure that Internet services operate independently from the global Internet, if necessary. State intervention in the Internet platform market can also have a different purpose. The user reads on the Internet not only what he is interested in, but what he is provided by the operator. In case of the state intervention, there is a significant impact on users also in terms of the availability of information and their possible political direction. Users can end up in the so-called "informational bubble" (Plavčan, Funta, 2019). Negative externalities of such behaviour may occur when these algorithms are used to target a particular group or individuals for specific political purposes, such as loss of privacy, creating a negative image of individuals, groups or states. The only way is to finance the education of the population and the education of critical thinking in schools of all levels. Political and professional decisions to increase education expenditure evidently positively affect the quality of education at schools in general, regardless of how the "economy is doing". The results of the analysis support the assumption that even in the case of a state's restrictive budget, expenditure on education and creative activity in general should not be restricted (Plavčan, 2019).

\section{Conclusion}

So far, government players have shown great reluctance to regulate dominant internet platforms. This can be attributed on the one hand to adherence to the belief in dynamic, selfregulating, functioning internet markets, and on the other hand to a certain overstraining in view of the scope of technological, social and economic innovations in connection with internet platforms and the associated uncertainty. This development can be explained by the economic peculiarities of the internet markets as network markets and the peculiarities of the innovation processes in such markets. The resulting monopoly situations have negative effects for everyone who uses internet platforms in some form, both private users and companies and organizations. While the sphere of influence of the dominant internet platforms encompasses more and more areas of life, their enormous importance is only slowly gaining awareness in other circles of society, economy and science. The largely invisible big data machinery is moving, at least as it appears, largely under the radar of state 
regulators. So far, answers are missing about the manifold challenges which arise from dominant internet platforms. The difficulty lies in the fact that they not only cross-national borders but also inter- and intradisciplinary borders. Accordingly, only a comprehensive solution that bridges these limits can counteract the risk of a regulatory patchwork. From a legal point of view, a wide range of areas are involved, which is why a comprehensive, sector-specific regulation should be given priority over selective changes in various laws at international and national level. This is the only way to ensure that the various legal elements are coordinated with one another and that all parties involved have clarity and legal certainty (Mazák, Jánošíková, 2011) with regard to the central regulatory aspects of internet platforms.

\section{References}

Beňová, E., Cibáková, V., Plavčan, P. (2005). Úvod do teórie verejného sektora. Bratislava: Merkury.

Daňko, M. (2019). Elektronické komunikácie vo svetle informatizácie spoločnosti. Mílniky práva $v$ stredoeurópskom priestore. Bratislava: Univerzita Komenského.

Daňko, M., Mesarčík, P. (2015). Zodpovednosi webového portálu za diskusné príspevky. Bratislavské právnické fórum 2015. Bratislava: Univerzita Komenského.

Daňko, M., Žárská, P. (2019). Data protection vs. Intellectual property. Počítačové právo, UI, ochrana údajov a najväčšie technologické trendy, Brno: MSD.

Elhauge, E. (2009). Tying, Bundled Discounts, and the Death of the Single Monopoly Profit Theory. Harvard Law Review, Vol. 123.

Funta, R. (2010). Abuse of a dominant position in EU and US Law. 1 edition, Brno: Tribun EU.

Funta, R. (2014). Some remarks on the Google ECJ ruling (C-131/12). Warszawa: Krytyka Prawa-Akademia Leona Kožmiňskiego, Tom 6.

Funta, R. (2016). Prípad Google: príležitosî alebo protekcioniznus? EU Law Journal, No. 02.

Funta, R. (2017). Politika hospodárskej sútaže EÚ a on-line platformy. EU Law Journal, No. 1.

Funta, R. (2018). Google \& Facebook vs. Art. 102 TFEU, Days of EU Law. Effects of EU law on national legislation, Győr: Széchenyi István University.

Funta, R. (2019). Úvod do počítačového práva. Brno: MSD.

Funta, R. (2020). Internet Platforms and Digital Economy. EU Law Journal, No. 1.

Funta, R., Golovko, L., Juriš, F. (2020). Európa a Európske právo. 2. doplnené a rozšírené vydanie, Brno: MSD.

Gregušová, D., Peráček, T. (2015). Obchodné právo pre manažérov. Bratislava: Univerzita Komenského.

Karas, V., Králik, A. (2012). Právo Európskej únie. 1. vydanie, Bratislava: C. H. Beck. Klimek, L. (2019). Criminal Responsibility for Market Abuse in European Legal Framework. EU Law Journal, No. 2.

Klimek, L. (2013). Effective Enforcement of Sanctions for Market Abuse in the EU: 
Introduction of Criminal Sanctions. Czech Yearbook of International Law, New York: Juris Publishing.

Králiková, K. (2016). Ludský faktor a jeho správanie na trhu výrobných faktorov. Európska spoločnosí a jej kultúra: zborník z medzinárodnej vedeckej konferencie, Warszawa: Szkola Wyzsa im. Bogdana Jańskiego.

LaVecchia, O., Mitchell, S. (2016). Amazon's Stranglehold: How the Company's Tightening Grip Is Stifling Competition, Eroding Jobs, and Threatening Communities. Washington DC: Institute for local self-reliance.

Machová, Z., Kotlán, I. (2014). Expenditures on Collective and Individual Services: Discussion on the Classification of Government Expenditures with Regard to their Inclusion into Growth Models. DANUBE: Law and Economics Review, 5(4).

Mazák, J., Jánošíková, M. (2009). Základy práva Európskej únie. Bratislava: Wolters Kluwer.

Mazák, J., Jánošíková, M. (2011). Lisabonská zmluva, ústavný systém a súdna ochrana. Bratislava: Iura Edition.

Mesarčík, M. (2018). GDPR a ochrana osobných údajov pre školy. Bratislava: Raabe.

Pelikánová, R. (2014). Divergence of antitrust enforcements-where, and where not, to collude. Antitrust, 5(2).

Petr, M., Tonarová, Z. (2010). Soutěžní právo, dominance a regulace „př́iliš vysokých“ cen. Pravní rozhledy, č. 12.

Plavčan, P. (2019). The comparison of PISA educational results with gross domestic product in member states of European Union. Prague: International Conference on Innovations and Science education. March 20-22, 2019. Journal Contact.

Plavčan, P., Funta, R. (2019). Údaje a ich úloha v politických kampaniach? Justičná revue, č. 10 .

Polčák, R. a kol. (2018). Právo informačních technologií. Praha: Wolters Kluwer.

Procházka, R., Káčer, M. (2013). Teória práva. Bratislava: C. H. Beck.

Procházka, R., Čorba, J. (2006). Právo Európskej únie. Bratislava: Poradca podnikatela.

Siman, M., Slaštan, M. (2010). Primárne právo EÚ. Bratislava: Euroiuris.

Stehlík, V., Hamulák, O., Petr, M. (2017). Právo Evropské unie: ústavní základy a vnitřní trh. Praha: Leges.

Stehlík, V. (2008). Právo Evropské unie v dokumentech. Univerzita Palackého v Olomouci, Právnická fakulta.

Svák, J. (2000). Zásady a tendencie v ochrane práva na súkromie. Justičná revue, č. 11. Svoboda, P., Munková, J., Kindl, J. (2012). Soutěžní právo. 2. vydání, Praha: C. H. Beck. Šmejkal, V. (2016). Výzvy pro evropský antitrust ve světě vícestranných online platforem. Antitrust: Revue soutěžního práva, č. 4.

Šmejkal, V. (2012). Ochrana spotřebitele a jeho blahobytu v soutěžním právu EU. AUC Iuridica, č. 3.

Whish, R., Bailey, D. (2018). Competition Law. 9th. Edition, Oxford: Oxford University Press. 